\title{
Mismatch Negativity (MMN) response studies in elderly subjects
}

Gabriela Buranelli ', Marcella Brito Barbosa ${ }^{2}$, Cristiane Fregonesi Dutra Garcia ${ }^{3}$, Sinésio Grace Duarte ${ }^{4}$, Antônio Carlos Marangoni ${ }^{5}$, Lucinda M. de F. Rodrigues Coelbo ${ }^{6}$, Ana Cláudia Mirândola Barbosa Reis ${ }^{7}$, Myriam de Lima Isaac ${ }^{8}$
Keywords: attention, auditory cortex, memory, evoked potentials.

\section{Summary}

\begin{abstract}
$\mathrm{M}$ ismatch Negativity is an endogenous potential which reflects the processing of differences incurred in the acoustic stimulus. Aim: to characterize MMN responses in elderly subjects and compare with adult subjects. Materials and methods: prospective study involving 30 subjects, 15 men and 15 women, aged between 60 and 80 years and 11 months. Statistical test: Mann-Whitney. The subjects went through medical evaluation, threshold tonal audiometry, immittance tests, otoacoustic emissions and short and long latency auditory potentials (MMN). Results: mean latency was $161.33 \mathrm{~ms}$ (CZA2) and $148.67 \mathrm{~ms}$ (CZA1), in women; of 171 $\mathrm{ms}(\mathrm{CZA} 2)$ and $159.07 \mathrm{~ms}$ (CZA1), men. Mean amplitude was $-2.753 \mu \mathrm{V}(\mathrm{CZA} 2)$ and $-2.177 \mu \mathrm{V}(\mathrm{CZA} 1)$, women; -1.847 $\mu \mathrm{V}$ (CZA2) and $-1.953 \mu \mathrm{V}$ (CZA1), men. As to the right and left hemispheres, mean latency variable of $166 \mathrm{~ms}$ (CZA2) and $153.87 \mathrm{~ms}$ (CZA1); for the amplitude variable, mean value of $-2.316 \mu \mathrm{V}$ (CZA2) and $-2.065 \mu \mathrm{V}$ (CZA1). Conclusion: there is no statistically significant difference between the latency and amplitude when we compared males and females, right and left sides in the elderly and between chronologic ages between adults and elderly subjects.
\end{abstract} School of Ribeirão Preto/SP - USP, Speech and hearing therapist. Professor of Speech and Hearing Therapy. University of Franca - Franca/SP.

PhD in Surgery - Medical School of Ribeirão Preto/SP - USP, MD. Neurologist. Professor at the Speech and Hearing Program - University of Franca - Franca/SP.

${ }^{5}$ MSc in Bioengineering - Medical School of Ribeirão Preto/SP - USP / EE São Carlos. MSc in Solid State Physics - IFUSP - São Paulo/SP. PhD Student of Sciences - University of Franca - Franca/SP. Physicist. Professor of the University of Franca.

${ }^{6}$ MSc in Bioengineering - Medical School of Ribeirão Preto/SP - USP / EE São Carlos. MSc in Solid State Physics - IFUSP - São Paulo/SP. PhD Student in Sciences - University of Franca - Franca/SP. Physicist. Professor of the University of Franca.

${ }^{7} \mathrm{PhD}$ in Human Communication Disorders - UNIFESP/SP. Speech and Hearing Therapist. Professor of Speech and Hearing Therapy - Department of Ophthalmology, Otorhinolaryngology and Head and Neck Surgery - Medical School of Ribeirão Preto/SP - USP.

${ }^{8} \mathrm{PhD}$ - Medical School of Ribeirão Preto/SP. Otorhinolaryngologist. Professor at the Department of Otorhinolaryngology, Ophthalmology and Head and Neck Surgery - Medical School of Ribeirão Preto/SP - USP.

Paper submitted to the BJORL-SGP (Publishing Management System - Brazilian Journal of Otorhinolaryngology) on August 24, 2008; and accepted on April 07, 2009. cod. 6002 


\section{INTRODUCTION}

The auditory system can be broken down into peripheral and central ${ }^{1}$. Threshold Tonal Audiometry (TTA) is the basis of any audiologic evaluation. Such tests establish the hearing thresholds and compare the values found with normal standards ${ }^{2}$. Hearing assessment by electrophysiological means aims at helping in the diagnostic and solution of hearing disorders ${ }^{3}$. Auditory Evoked Potentials (AEP) assess the neuroelectrical activity on the auditory pathway, from the auditory nerve all the way to the cerebral cortex, in response to a stimulus or acoustic event. They can be classified according to the latency in which they occur. Early AEP or short latency AEP happen in the first 10 milliseconds (ms), the medium latency potentials happen between 10 and $80 \mathrm{~ms}$ and the late or long latency ones happen between 80 and $750 \mathrm{~ms}^{4}$.

The Brainstem Auditory Evoked Potentials (BAEP) arise from the auditory nerve and auditory pathways of the brainstem. The general BAEP format includes a series of seven positive waves. Wave $\mathrm{V}$ is the response with the highest value, for it is the larger and the least variable one, and it persists even at low intensities ${ }^{3,4}$. Medium latency potentials are made up of a series of positive and negative waves. The first wave is the $\mathrm{Na}$, the second is the $\mathrm{Pa}$, afterwards we have the $\mathrm{Nb}, \mathrm{Pb}$ and, sometimes $\mathrm{Nc}$ and $\mathrm{Pc}^{5}$. Currently, medium latency potentials have been seen as one of the most promising electrophysiologic tests, capable of assessing Central Nervous System dysfunctions ${ }^{6}$. Long latency potentials are established by the attention the individual pays to the sound stimulus. These potentials originate from the primary and secondary areas of the auditory cortex and are useful to study cognitive functions and attention. They can be broken down into exogenous and endogenous ${ }^{4,7}$. The long latency potential called Mismatch Negativity - MMN - which is an endogenous potential, an automatic brain response which reflects the central processing of very subtle differences seen in the acoustic stimulus. This response is passive and does not require a behavioral response or attention ${ }^{4}$. The MMN is obtained by subtracting the wave of the infrequent stimuli from the wave of the frequent stimuli; then one obtains a third wave in which we can identify the presence of a potential of greater amplitude between the 100 and $250 \mathrm{~ms}$ amplitudes (Figure 1).

Having in mind the growth in the elderly population and the difficulty to find MMN test parameters in Brazil, we had this interest in studying its characterization, in these subjects, for its results help investigate Central Auditory System (CAS) functions. Some studies ${ }^{8,9}$ reported on the MMN response in normal adult subjects. Based on our findings, the present study compared the characteristics of the test in these different populations - adults and the elderly. The goal of this present study, therefore, is to

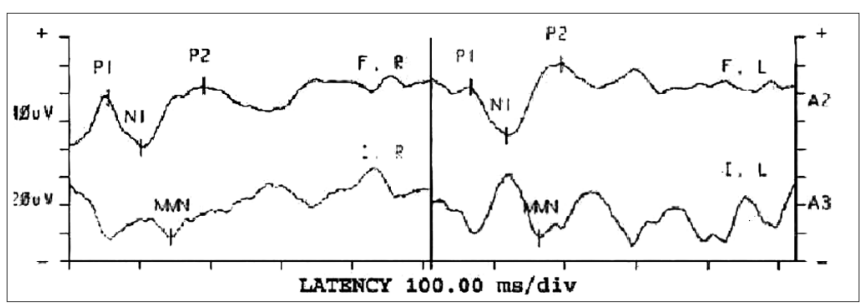

Figure 1. Results from the MMN test - ms - milliseconds P1/N1/P2 - Exogenous Potentials (Positive and Negative) F / I - Frequent / Infrequent R - Right; L - Left; MMN - Mismatch Negativity

characterize MMN response in the elderly, of both genders, with ages ranging between 60 and 80 years and 11 months; and to compare the MMN test characteristics in the adult and elderly populations.

\section{MATERIALS AND METHODS}

Prevalence study. Deductive method; descriptive, observational, cross-sectional, statistical, comparative and prospective. This research is focused on diagnostic purposes. The population in this study was made up of elderly subjects, with chronological age above that of 60 years, of both genders. The sample was made up of 15 men and 15 women, with ages ranging between 60 and 80 years and six months (Figure 2). The mean age for females was of 70 years and two months, and the minimum age was 60 years and five months and the maximum of 80 years and five months; for males, the mean age was 70 years; the minimum was 60 years and the maximum was 78 years and six months.

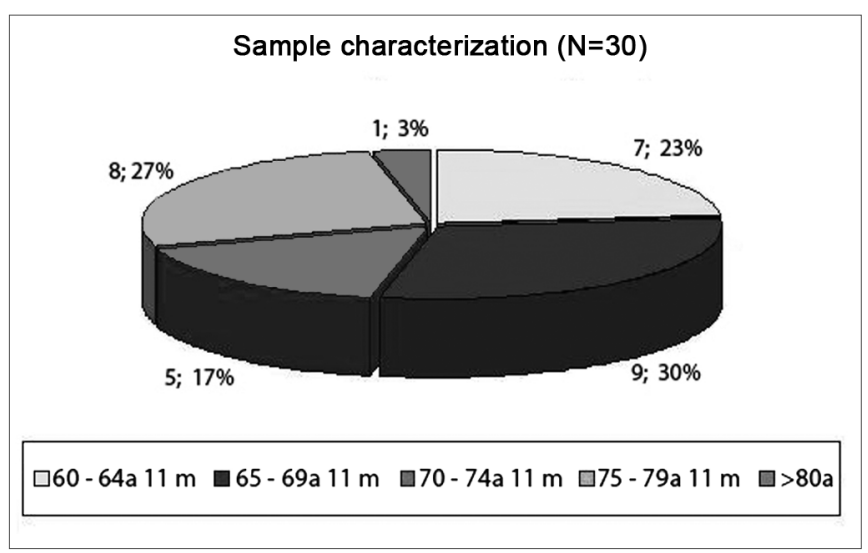

Figure 2. Study Sample Characterization $(\mathrm{N}=30)$ - N: number of subjects; a: years m: months

The dependent variables studied were the results from the MMN test and the independent variables were the CZA1 (left side), CZA2 (right side) leads; males and females; chronological age (adults and elderly). It is worth noticing that the data regarding the adults is present in two recent studies ${ }^{8,9}$. 
The equipment used were: HEINE mini 2000 Otoscope; (AC33 audiometer, TDH 39 phone), calibrated on October 18, 2007; middle ear analyzer (AZ-7), calibrated on October 18, 2007; ILO 292 OAE analyzer, version 5.0, Otodynamics LTDA, coupled to a conventional computer; Biologic version 5.70, model 317, two channels, coupled to a conventional computer; 29-inch Gradiente TV set; Philips DVD player; DVD (Movie) Green Alert.

Data collection procedures were carried out in the following stages: 1st stage: Approval from the Research Ethics Committee (approval \# 0018/08); 2st stage: Free and Informed Consent signed by the participants or persons responsible for them; 3rd stage: neurological medical evaluation, in order to establish clinical diagnoses and obtain data on the history of the subjects studied; 4th stage: individual interview with the participants in order to collect data on their hearing and general health status; 5th stage: Inspection of the external auditory meatuses before the proper tests were carried out; 6th stage: TTA tests, immittance tests in order to find the tonal thresholds and check the middle ear and central auditory conditions; 7th stage: OAE and BAEP tests in order to study the outer hair cells and the central auditory pathways, considering: trace morphology, absolute latency of waves I, III and V and interpeak latencies of intervals I-III, III$\mathrm{V}, \mathrm{I}-\mathrm{V}$, as well as amplitude relationships of waves I and V10. As to the transitory OAEs, they were absent, and the Distortion Product OAE (DPOAE) in order to check for result compatibility; 8th stage: MMN testing, with the same equipment used to do the BAEP, however with the patient wide awake, without paying attention to the test. The patient had to watch the "Green Alert" movie, while the waves were recorded. We used a pure tone for the rare and frequent stimuli in performing the MMN with one channel for data collection. Lead placement followed the international 10/20 standard $^{12}$, and the active lead $(\mathrm{Cz})$ was placed on the center of the head, on the scalp, on input jack 1 of the pre-amplifier; the A1 and E2 Reference Leads (left and right ears, respectively), were placed on the earlobes, the tested ear was on input Jack 2 of channel 1 and the contralateral was not plugged to the preamplifier. The ground lead (Fpz) was placed on the forehead, near the hairline. After wave recording, the ones obtained by subtracting the rare stimuli by the frequent stimuli in order to identify the presence of endogenous MMN potentials, considered between 100 and $250 \mathrm{~ms}$, of greater negative amplitude in this interval.

The test parameters were based on some stu$\operatorname{dies}^{4,8,9,11}$, with some adaptations for the present study, and we used the Tone Burst, with a gain of 15,000, intensity of $70 \mathrm{dBHL}$ for rare and frequent stimuli, frequency $1,000 \mathrm{~Hz}$ for the frequent stimulus and of $1,500 \mathrm{~Hz}$ for the infrequent stimuli, 30.0 filter for the high frequencies and 1.0 for the low frequencies, 512 analysis time, supra-aural phone (TDH-39), rarefaction polarity, stimuli relation set on 5 . For the sample, we used approximately 400 frequent stimuli (80\%) and 100 infrequent stimuli (20\%).

As to data analysis, in order to compare the genders, ear side and ages (adults and elderly) in terms of MMN amplitude and latency measures, we used the MannWhitney statistical test, because they are continuous values, measured in an interval scale of different groups, without any populational distribution of the variables ${ }^{13}$. The significance level ( $\mathrm{p}$ value) was established on $5 \%(\mathrm{p}=0.05)$.

\section{RESULTS}

Table 1 shows the statistical data regarding the TTA test, for the subjects of both genders in the same sample, for the right and left ears.

On Table 2 we describe the values regarding the MMN test latency variable, obtained from the assessment of both genders on the CZA1 and CZA2 leads. Table 3 describes the values related to the MMN amplitude, obtained from assessing both genders on leads CZA1 and CZA2. On Table 4 we describe the values related to the MMN amplitude and latency obtained on the assessment of the entire sample, from leads CZA1 and CZA2.

Figures 3 and 4 show the amplitude and latency values, of leads CZA2 and CZA1 of the MMN test of the

Table 1. TTA value description according to gender.

\begin{tabular}{ccccc}
\hline Left ear & Women $(\mathrm{N}=15)$ & Men $(\mathrm{N}=15)$ & Right ear & Women $(\mathrm{N}=15)$ \\
\hline Minimum & $10 \mathrm{dBHL}$ & $10 \mathrm{dBHL}$ & Minimum & $10 \mathrm{dBHL}$ \\
Maximum & $45 \mathrm{dBHL}$ & $90 \mathrm{dBHL}$ & Maximum & $45 \mathrm{dBHL}$ \\
Mean & $26 \mathrm{dBHL}$ & $33,33 \mathrm{dBHL}$ & Mean & $26,33 \mathrm{dBHL}$ \\
Median & $25 \mathrm{dBHL}$ & $25 \mathrm{dBHL}$ & Median & $25 \mathrm{dBHL}$ \\
Standard Deviation & 10,036 & 22,414 & Standard Deviation & 9,904 \\
p value 0.7084 & & & p value 0,5330 & \\
\hline
\end{tabular}

Legend: $\mathrm{dBHL}=$ deciBel Hearing Level 
Table 2. MMN latency, $\mathrm{CZA}_{2}$ and $\mathrm{CZA}_{1}$ lead value description according to gender.

\begin{tabular}{cccccc}
\hline $\begin{array}{c}\text { Right side } \\
\left(\mathrm{CZA}_{2}\right)\end{array}$ & Women $(\mathrm{N}=15)$ & Men $(\mathrm{N}=14)$ & Left side $\left(\mathrm{CZA}_{1}\right)$ & Women $(\mathrm{N}=15)$ & Men $(\mathrm{N}=15)$ \\
\hline Minimum & $108 \mathrm{~ms}$ & $102 \mathrm{~ms}$ & Minimum & $108 \mathrm{~ms}$ & $100 \mathrm{~ms}$ \\
Maximum & $240 \mathrm{~ms}$ & $250 \mathrm{~ms}$ & Maximum & $232 \mathrm{~ms}$ & $224 \mathrm{~ms}$ \\
Mean & $161,33 \mathrm{~ms}$ & $171 \mathrm{~ms}$ & Mean & $148,67 \mathrm{~ms}$ & $159,07 \mathrm{~ms}$ \\
Median & $152 \mathrm{~ms}$ & $164 \mathrm{~ms}$ & Median & $142 \mathrm{~ms}$ & $154 \mathrm{~ms}$ \\
Standard Deviation & 43,086 & 47,947 & Standard Deviation & 33,404 & 37,841 \\
p value 0,5854 & & & p value 0,3615 & & \\
\hline
\end{tabular}

Legend: $\mathrm{ms}=$ milliseconds

Table 3. Description of the amplitude values of the MMN, CZA and CZA, leads, according to gender.

\begin{tabular}{|c|c|c|c|c|c|}
\hline $\begin{array}{l}\text { Right side } \\
\left(\mathrm{CZA}_{2}\right)\end{array}$ & Women $(\mathrm{N}=15)$ & Men $(N=14)$ & Left side $\left(C Z A_{1}\right)$ & Women $(\mathrm{N}=15)$ & $\operatorname{Men}(N=15)$ \\
\hline Minimum & $-0,600 \mu \mathrm{V}$ & $-0,290 \mu \mathrm{V}$ & Minimum & $-0,070 \mu \mathrm{V}$ & $-0,330 \mu \mathrm{V}$ \\
\hline Maximum & $-7,710 \mu \mathrm{V}$ & $-5,720 \mu \mathrm{V}$ & Maximum & $-3,960 \mu \mathrm{V}$ & $-3,750 \mu \mathrm{V}$ \\
\hline Mean & $-2,753 \mu \mathrm{V}$ & $-1,847 \mu \mathrm{V}$ & Mean & $-2,177 \mu \mathrm{V}$ & $-1,953 \mu \mathrm{V}$ \\
\hline Median & $-2,740 \mu \mathrm{V}$ & $-1,135 \mu \mathrm{V}$ & Median & $-2,280 \mu \mathrm{V}$ & $-1,980 \mu \mathrm{V}$ \\
\hline Standard deviation & 1,762 & 1,817 & Standard deviation & 1,093 & 1,095 \\
\hline$p$ value 0,1121 & & & $p$ value 0,6236 & & \\
\hline
\end{tabular}

Legend: $\mu \mathrm{V}=$ microVolts

Table 4. Description of MMN amplitude and latency values and those for $C Z A_{2}$ and $C Z A_{1}$ leads, of subjects of the same gender.

\begin{tabular}{|c|c|c|c|c|c|}
\hline Latency (ms) & $\begin{array}{c}\text { Right side } \\
\left(\mathrm{CZA}_{2}\right) \mathrm{N}=29\end{array}$ & $\begin{array}{c}\text { Left side } \\
\text { (CZA1) } \mathrm{N}=30\end{array}$ & Amplitude $(\mu \mathrm{V})$ & $\begin{array}{c}\text { Right side } \\
\left(\mathrm{CZA}_{2}\right) \mathrm{N}=29\end{array}$ & $\begin{array}{c}\text { Left side } \\
\left(\mathrm{CZA}_{1}\right) \mathrm{N}=30\end{array}$ \\
\hline Minimum & $102 \mathrm{~ms}$ & $100 \mathrm{~ms}$ & Minimum & $-0,290 \mu \mathrm{V}$ & $-0,070 \mu \mathrm{V}$ \\
\hline Maximum & $250 \mathrm{~ms}$ & $232 \mathrm{~ms}$ & Maximum & $-7,710 \mu \mathrm{V}$ & $-3,960 \mu \mathrm{V}$ \\
\hline Mean & $166 \mathrm{~ms}$ & $153,87 \mathrm{~ms}$ & Mean & $-2,316 \mu \mathrm{V}$ & $-2,065 \mu \mathrm{V}$ \\
\hline Median & $156 \mathrm{~ms}$ & $150 \mathrm{~ms}$ & Median & $-1,990 \mu \mathrm{V}$ & $-2,135 \mu \mathrm{V}$ \\
\hline Standard deviation & 44,941 & 35,467 & Standard deviation & 1,816 & 1,081 \\
\hline$p$ value 0,35111 & & & $p$ value 0,9637 & & \\
\hline
\end{tabular}

Legend: $\mathrm{ms}=$ milliseconds; $\mu \mathrm{V}=$ microVolts

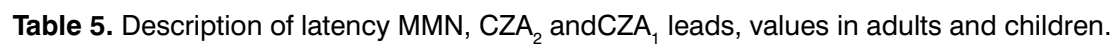

\begin{tabular}{|c|c|c|c|c|c|}
\hline $\begin{array}{l}\text { Right side } \\
\left(\mathrm{CZA}_{2}\right)\end{array}$ & $\begin{array}{l}\text { Adults } \\
(\mathrm{N}=12)\end{array}$ & $\begin{array}{l}\text { Elderly } \\
(\mathrm{N}=29)\end{array}$ & $\begin{array}{l}\text { Left side } \\
\left(\mathrm{CZA}_{1}\right)\end{array}$ & $\begin{array}{l}\text { Adults } \\
(\mathrm{N}=12)\end{array}$ & $\begin{array}{l}\text { Elderly } \\
(\mathrm{N}=30)\end{array}$ \\
\hline Minimum & $150,20 \mathrm{~ms}$ & $102 \mathrm{~ms}$ & Minimum & $150,20 \mathrm{~ms}$ & $100 \mathrm{~ms}$ \\
\hline Maximum & $245,20 \mathrm{~ms}$ & $250 \mathrm{~ms}$ & Maximum & $224,20 \mathrm{~ms}$ & $232 \mathrm{~ms}$ \\
\hline Mean & $168,62 \mathrm{~ms}$ & $166 \mathrm{~ms}$ & Mean & $160,53 \mathrm{~ms}$ & $153,87 \mathrm{~ms}$ \\
\hline Median & $154,70 \mathrm{~ms}$ & $156 \mathrm{~ms}$ & Median & $152,70 \mathrm{~ms}$ & $150 \mathrm{~ms}$ \\
\hline Standard deviation & 29,352 & 44,941 & Standard deviation & 21,588 & 35,467 \\
\hline p value 0,6778 & & & p value 0,3958 & & \\
\hline
\end{tabular}

Legend: $\mathrm{ms}=$ milliseconds 


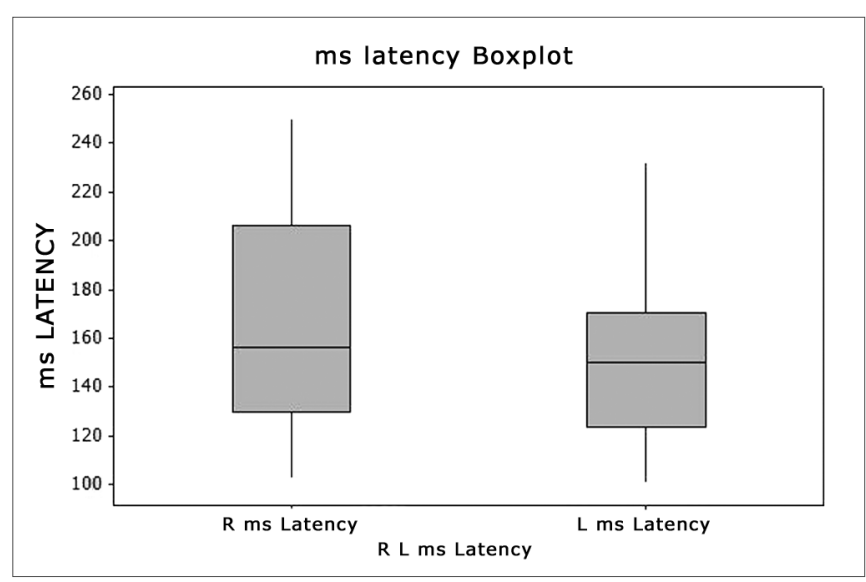

Figure 3. Boxplot - Latency Right and Left sides -ms - milliseconds $R$ - Right ( $N=30$ ears) $L$ - Left ( $N=29$ ears)

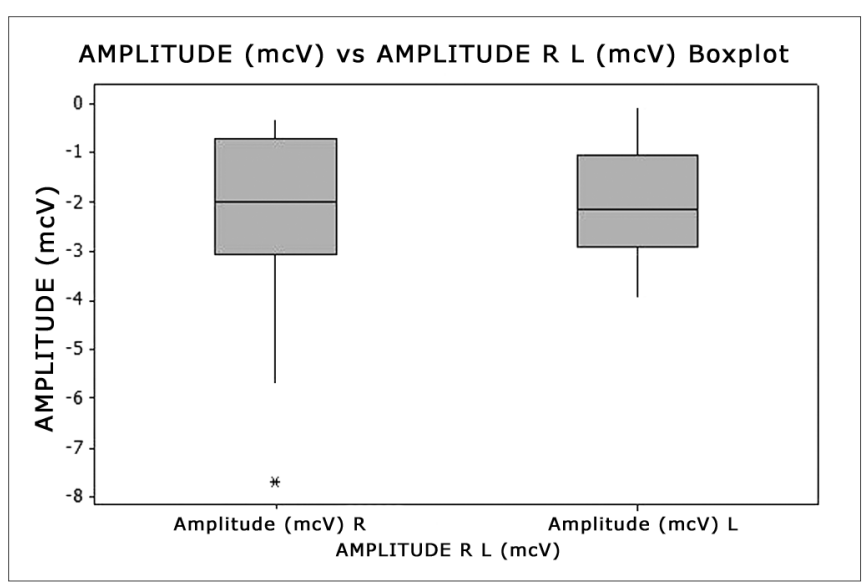

Figure 4. Boxplot - Amplitude Right and Left sides - $\mathrm{mcV}$ - microVolts $R$ - Right ( $N=30$ ears) $L$ - Left ( $N=29$ ears)

Table 6. MMN amplitude. $\mathrm{CZA}_{2}$ and $\mathrm{CZA}_{1}$ leads values from adults and children.

\begin{tabular}{cccccc}
\hline $\begin{array}{c}\text { Right Side } \\
\left(\mathrm{CZA}_{2}\right)\end{array}$ & $\begin{array}{c}\text { Adults } \\
(\mathrm{N}=12)\end{array}$ & $\begin{array}{c}\text { Elderly } \\
(\mathrm{N}=29)\end{array}$ & $\begin{array}{c}\text { Left side } \\
\left(\mathrm{CZA}_{1}\right)\end{array}$ & $\begin{array}{c}\text { Adults } \\
(\mathrm{N}=12)\end{array}$ & $\begin{array}{c}\text { Elderly } \\
(\mathrm{N}=29)\end{array}$ \\
\hline Minimum & $-0,500 \mu \mathrm{V}$ & $-0,290 \mu \mathrm{V}$ & Minimum & $-0,300 \mu \mathrm{V}$ & $-0,070 \mu \mathrm{V}$ \\
Maximum & $-9,450 \mu \mathrm{V}$ & $-7,710 \mu \mathrm{V}$ & Maximum & $-9,420 \mu \mathrm{V}$ & $-3,960 \mu \mathrm{V}$ \\
Mean & $-2,691 \mu \mathrm{V}$ & $-2,316 \mu \mathrm{V}$ & Mean & $-2,596 \mu \mathrm{V}$ & $-2,065 \mu \mathrm{V}$ \\
Median & $-2,180 \mu \mathrm{V}$ & $-1,990 \mu \mathrm{V}$ & Median & $-1,585 \mu \mathrm{V}$ & $-2,135 \mu \mathrm{V}$ \\
Standard Deviation & 2,596 & 1,816 & Standard Deviation & 2,535 & 1,081 \\
p value 0,8748 & & & p value 0,9778 & & \\
\hline
\end{tabular}

Legend: $\mu \mathrm{V}=$ microVolts

entire sample $(\mathrm{N}=30)$, according to the statistical analysis, by means of the Boxplot graph.

In a second stage, we compared the groups of different chronological ages - adults and elderly. Data regarding the adults was obtained in the studies, ${ }^{8,9}$. Data regarding the elderly are the findings of the present study. Tables 5 and 6 describe the values regarding the latency and amplitude variables of the MMN exam, obtained on the assessment of adults and elderly from leads CZA1 and CZA2.

\section{DISCUSSION}

The study sample was made up of thirty subjects, 15 women and 15 men (Figure 2). According to the statistical analysis, the minimum age for males and females was sixty years and five months; maximum age was 78 years and six months for males. Mean age for women was seventy years and two months and for males was seventy years. Comparing ages based on gender we noticed that there was no significant difference $(\mathrm{p}=0.9504)$. Life expectancy has increased and, for this reason, the population of the present study was chosen as the variable to be studied. Law 10.741/03 considers those above 60 years of age as elderly citizens ${ }^{14}$.
For data collection purposes, we carried out a basic hearing evaluation by means of the TTA, Speech Recognition Threshold (SRT), Speech Recognition Index (SRI) and immittance studies. According to Table 1, we did not observe significant statistical differences regarding right and left ears, females and males $(\mathrm{p}=0.5330 ; \mathrm{p}=0.7084$, respectively). The tonal threshold mean value for the right ear was 26.33 decibel Hearing Level (dBHL), for females and $31.33 \mathrm{dBHL}$ for males. Minimum and maximum limits were $10 \mathrm{dBHL}$ and $45 \mathrm{dBHL}$, right and left ears, for females; and in $10 \mathrm{dBHL}$ and $90 \mathrm{dBHL}$, left ear for males. Based on this data, we diagnosed mild hearing loss, according to the mean values for both ears in both genders.

According to the literature studied, presbycusis is defined as the hearing loss stemming from an increase in chronological age ${ }^{15}$. According to other authors ${ }^{16,17}$, the audiometric configuration of the elderly is usually a descending curve. For our analysis, the mean value of tonal thresholds was obtained according to the results of frequencies 500, 1 kilo (k), 2k and 3k Hertz (Hz). Therefore, the high frequencies, usually the ones impaired in the elderly population were not considered in this summation. That is why the level of hearing loss was non-significant 
in this study - contradictory to one study ${ }^{18}$, nonetheless matching another ${ }^{19}$. The tonal mean value by air conduction proposed 3 involves the thresholds of frequencies of $500,1 \mathrm{k}$ and $2 \mathrm{kHz}$. We adapted our study to increase the frequency threshold to $3 \mathrm{kHz}$, in order to have a better evaluation of the entire cochlea, from base to apex. Results indicate a greater involvement of males - maximum and mean values according to the statistical analysis - not matching a study already carried out ${ }^{20}$. As far as logoaudiometry, SRT and SRI are concerned, the results from both ears on most of the subjects examined were compatible with the TTA. Except for the left ear of subject 29 - in whom we carried out the LDV, because of the profound hearing loss in this ear. The SRI was not compatible for both right and left ear, subject 19 and left ear for subject 24 . We did not find data on the interview which would justify such result; therefore, we believe this may have happened because of the very advanced chronologic age, a hypothesis which was also mentioned in some studies ${ }^{17,20}$. In the immittance test, we found $48.3 \%$ (29 ears) with type A tympanogram; 46.6\% (28 ears), type As; 1.7\% (1 ear) for curves Ad and $\mathrm{C}$, besides one ear in which we could not properly seal the external acoustic meatus. Unmatching ${ }^{20}$ and matching ${ }^{21}$ findings, since the latter found in their sample a major occurrence of curve As among the elderly, which indicate a tympanic-ossicular stiffness, justified by the chronologic age. The percentage number of type A curves (48.3\%), matched the type of sensorineural hearing loss seen in the sample subjects. As to the results of the stapedial reflex studies, we have observed that the present and/or absent responses matched the hearing threshold in the frequency tested. The DPOAE were studied and, when present, we completed the evaluation with the DPOAE. The goal was to check the outer hair cells of the inner ear. The present or absent responses matched the level of hearing in each ear, considering that the TOAE are present in people who can listen up to 30dBHL and DPOAE up to 50dBHL. In order to record the BAEP(s) we used adequate response criteria (35\%, 21 ears), altered (48.3\%, 29 ears) and wave I higher than wave $\mathrm{V}$ (16.7\%, ten ears). In most of them, therefore, it presented an altered result (48.3\%). This data matched that from some studies ${ }^{7,22,23}$, which assign such fact to the increase in chronological age.

According to the literature, the Long Latency Auditory Evoked Potential (LLAEP) happens between 80 and $750 \mathrm{~ms}^{4,11}$. In our study, we found MMN-LLAEP between 100 and $250 \mathrm{~ms}$.

Table 2 shows the results, according to the statistical treatment, regarding latency. For the right side (CZA2) the minimum value was $108 \mathrm{~ms}$ for females and $102 \mathrm{~ms}$ for males; the maximum value found was $240 \mathrm{~ms}$ for females, and $250 \mathrm{~ms}$ for males; the mean values was $161.33 \mathrm{~ms}$ for females and $171 \mathrm{~ms}$ for males. We did not find statistically significant differences $(\mathrm{p}=0.5854)$ for the right side when genders were compared. For the left side (CZA1), the minimum value was $108 \mathrm{~ms}$ for females and $100 \mathrm{~ms}$, for men; the maximum value was $232 \mathrm{~ms}$ for women and $224 \mathrm{~ms}$ for men; the mean value was $148.67 \mathrm{~ms}$ for women and $159.07 \mathrm{~ms}$ for males. We did not find statistically significant difference $(p=0.3615)$ for the left side, when the genders were compared.

Table 3 shows the results regarding amplitude. For the right side (CZA2), the minimum value was $-0.600 \mu \mathrm{V}$ for women and $-0.290 \mu \mathrm{V}$ for men; the maximum value was $-7.710 \mu \mathrm{V}$ for women, and $-5.720 \mu \mathrm{V}$ for men; the mean value was $-2.753 \mu \mathrm{V}$ for women and $-1.847 \mu \mathrm{V}$ for men. There was no statistically significant difference $(p=0.1121)$ for the right side between the genders. For the left side (CZA1), the minimum value was $-0.070 \mu \mathrm{V}$ for females and $-0.330 \mu \mathrm{V}$ for males; the maximum value was $-3.960 \mu \mathrm{V}$ for women and $-3.750 \mu \mathrm{V}$ for men; the mean value was $-2.177 \mu \mathrm{V}$ for women and $-1.953 \mu \mathrm{V}$ for men. There was no statistically significant difference $(\mathrm{p}=0.6236)$ considering the left side for both genders.

We have also analyzed the latency and amplitude variables in the entire sample tested, a total of 29 subjects, 29 right ears and thirty left ears, since it was not possible to assess the right ear of subject \# 24 because of the excessive number of artifacts, because of muscle pains reported by the patient.

Table 4 describes the latency in its different values: for the right ear the minimum was $102 \mathrm{~ms}$, a maximum value of $250 \mathrm{~ms}$ and the mean value was $100 \mathrm{~ms}$; for the left side the maximum value was $232 \mathrm{~ms}$ and the mean value was $153.87 \mathrm{~ms}$. We did not find statistically significant differences $(p=0.3511)$ between the sides for the amplitude variable. Table 4 also describes the amplitude in its different values: for the right side, the minimum was $0.290 \mu \mathrm{V}$, and the maximum was $-7.710 \mu \mathrm{V}$ and the mean value was $-2.316 \mu \mathrm{V}$; for the left side the minimum was $-0.070 \mu \mathrm{V}$, maximum was $-3.960 \mu \mathrm{V}$ and the mean value was $-2.065 \mu \mathrm{V}$. We did not find statistically significant difference $(p=0.9637)$ between the sides regarding the amplitude variable. We can see the graph that shows these variables on Figs. 3 and 4.

A study which did a LLAEP ${ }^{24}$ with senior citizens concluded that the exogenous potential latency (N1 and P2) was not affected in the presence of a hearing disorder. Such data was not discussed in our study. Other authors ${ }^{25,26}$ advocate the idea that the perception of simultaneous sounds is made difficulty with the normal aging of the population, and this is the method of presentation of stimuli in the MMN test. In the literature studied we did not find MMN studies with elderly citizens showing latency and amplitude values.

Recent studies with adults ${ }^{8,9}$, found mean latency values for the right side of $153.2 \mathrm{~ms}$ and for the left side at $150.7 \mathrm{~ms}$ for females; for the right side it was $184 \mathrm{~ms}$ 
and for the left side it was $170.4 \mathrm{~ms}$ for men in the MMN test. The mean amplitude for women was $-3.548 \mu \mathrm{V}$ (right side) and $-2.757 \mu \mathrm{V}$ (left side); and for men it was $-1.867 \mu \mathrm{V}$ (right side) and $-1.435 \mu \mathrm{V}$ (left side). They have reported statistically significant differences between the genders in both sides - lower latency for women; amplitude did not show statistically significant differences; nonetheless it was higher in women. In comparison to our findings, the mean latency was higher in the right side of the present study (161.33ms) and lower for the left side (148.67ms) for women. For men, latency was lower for both the right and left sides (171ms and $159.07 \mathrm{~ms}$, respectively). As far as the amplitude is concerned, our findings were lower for the right side $(-2.753 \mu \mathrm{V})$ and for the left side $(-2.177 \mu \mathrm{V})$ among women. For men, it was lower on the right side $(-1.847 \mu \mathrm{V})$ and on the left side $(-1.953 \mu \mathrm{V})$. Another study 27 which evaluated subjects with severe and profound hearing loss (LLAEP - P300) reported mean latency of 371.3ms (right side) and 364.3ms (left side), at the age range between 25 and 45 years; and such data cannot be compared to our study, because it is a positive potential and not a negative one, like the MMN.

Some scholars ${ }^{28}$ observed that the latency is higher in adults and elderly patients when compared to their younger counterparts with the MMN. We compared the data associated with the elderly (present study) and adults (previous study ${ }^{8,9}$ ), shown on Tables 5 and 6 .

Table 5 shows the data associated with the latency variable. For the right side in adults ( $\mathrm{N}=12$ ears) the mean value was $168.62 \mathrm{~ms}$, the minimum value was $150.20 \mathrm{~ms}$ and the maximum was $245.20 \mathrm{~ms}$. For the elderly $(\mathrm{N}=29$ ears), the mean value was $166 \mathrm{~ms}$, the minimum value was $102 \mathrm{~ms}$ and the maximum was $250 \mathrm{~ms}$. We did not find statistically significant differences $(p=0.6778)$ among the ages, on the right side. For the left side, for adults $(\mathrm{N}=12$ ears), the mean value was $160.53 \mathrm{~ms}$, the minimum value was $150.20 \mathrm{~ms}$ and the maximum was $224.20 \mathrm{~ms}$. For the elderly ( $\mathrm{N}=30$ ears), the mean value was $153.87 \mathrm{~ms}$, the minimum value was $100 \mathrm{~ms}$ and the maximum was $232 \mathrm{~ms}$. There was no statistically significant difference $(p=0.3958)$ among the ages for the left side.

On Table 6 we see that the amplitude had a mean value of $-2.691 \mu \mathrm{V}$, the minimum value was $-0.500 \mu \mathrm{V}$ and the maximum was $-9.450 \mu \mathrm{V}$, for adults $(\mathrm{N}=12$ ears) for the right side. For the elderly ( $\mathrm{N}=29$ ears), in this same side the mean value was $-2.316 \mu \mathrm{V}$, the minimum value was $-0.290 \mu \mathrm{V}$ and the maximum value was $-7.710 \mu \mathrm{V}$. There was no statistically significant difference $(\mathrm{p}=0.8748)$ among the ages considering the amplitude variable for the right side. The amplitude had a mean value of $-2.596 \mu \mathrm{V}$, the minimum value was $-0.300 \mu \mathrm{V}$ and the maximum was $-9.420 \mu \mathrm{V}$ for adults ( $\mathrm{N}=12$ ears), left side. For this same side, the elderly $(\mathrm{N}=30$ ears) showed a mean value of $-2.065 \mu \mathrm{V}$, minimum value of $-0.070 \mu \mathrm{V}$ and a maximum of $-3.960 \mu \mathrm{V}$. We did not notice statistically significant differences $(p=0.6778)$ among the ages for the left side, considering the amplitude variable.

As it was found in the study 26 which assessed subjects between 25 and 55 years and compared the healthy group with the group with Multiple Sclerosis (MS) and did not find statistically significant differences regarding the latency and amplitude variables, our study reports that the values of these variables in a group of higher chronological age (mean of seventy years for men and seventy years and two months for women), in subjects without significant clinical involvement (health status evaluated by the physician who participated in the study) and we also did not notice statistically significant differences in these variables, between the genders and, with one more data, between the left and right sides. Thus, as it happened in prior studies ${ }^{8,9}$, we did notice, even without statistically significant differences, that the latency was lower and the amplitude was higher among women in the entire sample assessed in our study.

\section{CONCLUSION}

There was no statistically significant difference when we compared the MMN characteristic variables, latency and amplitude, between elderly men and women comparing the right and left sides. There was no statistically significant difference between the chronological ages of adults and elderly.

\section{REFERENCES}

1. Aquino AMCM de, Araújo MS de. Vias auditivas periférica e central. Em: Aquino AMCM de, editor. Processamento Auditivo: eletrofisiologia e psicoacústica. São Paulo: Lovise;2002. p. 17-31.

2. Marini AL, Halpern R, Aerts D. Sensibilidade, especificidade e valor preditivo da queixa auditiva. Rev Saúde Pública. 2005;39(6):982-4.

3. Santos TMM, Russo ICP. A prática da audiologia clínica. São Paulo: Cortez; 1986.

4. Junqueira CAO, Frizzo ACF. Potenciais evocados auditivos de curta, média e longa latência. Em:Aquino AMCM de, editor. Processamento auditivo: eletrofisiologia e psicoacústica. São Paulo: Lovise; 2002. p. 63-86.

5. Musiek FE, Lee WW. Potenciais auditivos de média e longa latência. Em: Musiek FE, Rintelmann WF, editores. Perspectivas atuais em avaliação auditiva. Barueri: Manole; 2001. p. 239-67.

6. Schochat E, Rabelo CM, Loreti RCA. Sensitividade e especificidade do potencial de média latência. Rev Bras Otorrinolaringol. 2004;70(3):353-8.

7. Matas CG, Juan KR de, Nakano RA. Potenciais evocados auditivos de média e longa latência em adultos com AIDS. Pró-fono. 2006;18(2):171-6.

8. Brossi AB, Borba KC, Garcia CFD. Verificação das respostas do Mismatch Negativity (MMN) em sujeitos adultos normais [Trabalho de Conclusão de Curso]. Franca (SP): Universidade de Franca; 2005.

9. Brossi AB, Borba KC, Garcia CFD, Reis ACMB, Isaac M de L. Verificação das respostas do Mismatch Negativity (MMN) em sujeitos adultos normais. Braz J Otorrinolaryngol. 2007;73(6):793-802.

10. Carvallo RMM. Processamento auditivo: avaliação audiológica básica. Em:Pereira LD, Schochat E, editores. Processamento auditivo central: manual de avaliação. São Paulo: Lovise; 1997. p. 28-35. 
11. Schochat E. Avaliação eletrofisiológica da audição. Em: Ferreira LP, Befy-Lopes DM, Limongi SCO, editores. Tratado de Fonoaudiologia. São Paulo: Roca;2004. p. 656-68.

12. Jasper, HH. The ten twenty electrode system of the international federation. Electroencephalogr Clin Neurophysiol. 1958;10:371-5.

13. Levine DM, Berenson ML, Stephan D. Estatística: teoria e aplicações. Rio de Janeiro: Livros Técnicos e científicos; 1998.

14. Veras RP, Mattos LC. Audiologia do envelhecimento: revisão de literatura e perspectivas atuais. Braz J Otorrinolaryngol. 2007;73(1):128-34.

15. Bess HF, Williams AH, Lichtenstein MJ. Avaliação audiológica dos idosos. Em: Musiek FE, Rintelmann WF, editores. Perspectivas atuais em avaliação auditiva. Barueri: Manole; 2001. p. 343-69.

16. Weinstein BE. Presbiacusia. Em: Katz J, editor. Tratado de audiologia clínica. São Paulo: Manole; 1999. p. 562-75.

17. Baraldi G dos S, Almeida LC, Borges AC de C. Evolução da perda auditiva no decorrer do envelhecimento. Braz J Otorrinolaryngol. 2007;73(1):844-8.

18. Ribeiro A. Aspectos biológicos do envelhecimento. Em: Russo ICP, editor. Intervenção fonoaudiológica na terceira idade. Rio de Janeiro: Revinter; 1999. p. 1-24.

19. Tanaka MRT, Araújo VM, Assencio-Ferreira VJ. Déficits de audição em idosos dificultariam a comunicação? Rev Cefac. 2002;4(3):203-5.

20. Greco MC, Russo ICP. Achados audiológicos de indivíduos idosos atendidos em uma clínica particular de São Paulo-SP. Acta ORL Técnicas em Otorrinolaringologia. 2006;24(4):245-54.
21. Bilton T, Viúde A, Sanchez PE. Fonoaudiologia. Em: Freitas VE de PYL, Neri LA, Cançado XAF, Gorzoni LM, Rochams da, editores. Tratado de Geriatria e Gerontologia. Rio de Janeiro: Guanabara Koogan; 2002. p. 820-7.

22. Jacob Filho W. Fisiologia do envelhecimento: Geriatria e Gerontologia para o Neurologista. Anais do 28th Congresso Brasileiro de Neurologia; 1998; São Paulo, Brasil. São Paulo, Academia Brasileira de Neurologia; 1998.

23. Irvine DRF. Auditory cortical plasticity: does it provide evidence for cognitive processing in the auditory cortex? Hear Res. 2007;229(12):158-70.

24. Cóser SJM, Cioquetta E, Pedroso SF, Coser LP. Potenciais auditivos evocados corticais em idosos com queixa de dificuldade de compreensão da fala. Arq Int Otorrinolaringol. 2007;11(4):396-401.

25. Alain C, McDonald KL. Age-related differences in neuromagnetic brain activity underlying concurrent sound perception. J Neurosci. 2007;27(6):1308-14.

26. Santos MAR, Munhoz MSL, Peixoto MAL, Haase VG, Rodrigues JL, Resende LM. Contribuição do Mismatch Negativity na avaliação cognitiva de indivíduos portadores de esclerose múltipla. Braz J Otorrinolaryngol. 2006;72(6):800-8.

27. Reis ACMB, Iório MCM. P300 em sujeitos com perda auditiva. ProFono. 2007;19(1):113-22.

28. Mueller V, Brehmer Y, Oertzen T, Shu-Chen L, Lindenberger U. Electrophysiological correlates of selective attention: a lifespan comparison. BMC Neurosci. 2008;9(1):9-18. 